\title{
State of the Agricultural Sector Technical Efficiency: The Case Study of African Countries
}

\author{
Khaled Abdou, \\ Fadi abdelradi \\ Department of Agricultural Economics, Faculty of Agriculture, Cairo University
}

\begin{abstract}
The purpose of this study is to compare the efficiency ratings of agricultural sectors for Africa countries. To do so, we use a True Random Effects model following (9). We further investigate the factors that affect technical inefficiency levels, which are expressed as a linear function of explanatory variables reflecting sector characteristics. Our analysis uses panel data for 26 African countries categorized into four groups based on geographical proximity (North, South, Centre and West) of Africa for the time period 1961-2011. A preliminary descriptive analysis suggests several differences among the four groups specially in fertilizer use and machinery. Empirical results show that production inputs like labour and machinery appear are found to be the most productive factors in North Africa compared with other groups. Additionally, all groups are characterized by increasing returns to scale which gives them an opportunity for more investments. Efficiency scores, on average, is around 0.146 for all African countries with the highest in Central Africa with 0.735 and lowest in North Africa. Regarding the factors that affect technical inefficiency, two indicators are identified; total value of agricultural exports and area equipped for irrigation.
\end{abstract}

Keywords: technical efficiency, true random effects model, Africa

\section{Introduction}

Over the last decade, agricultural production technical efficiency analysis has received considerable attention with different applications to cross-section and panel data estimation focusing on differences between developed and developing countries $(10,11,13,22)$. Studying technical efficiency is essential because it is considered as a prerequisite for economic efficiency, which ensures the economic feasibility and sustainability of the industry (23). Assessment of an industry's technical efficiency levels helps to identify the rational input allocation to achieve the required output levels which helps strengthening the capacity of the industry to face changing market conditions and increased input costs. It is also relevant for policymakers who are concerned with improving the economic performance and competitiveness.

In the majority of efficiency literature, Data Envelopment Analysis (DEA) a nonparametric approach and Stochastic Frontier Analysis (SFA) a parametric approach have been used interchangeably (see, for example, 16, 20, 21, 23, 24). A relevant 


\section{The Case Study of African Countries}

difference between the DEA and the SFA approaches is that the SFA allows for the stochastic component of production which makes it suitable for assessing the performance of production processes including random variables. Agricultural production technologies are considered stochastic, owing to the unexpected weather variations and other farm factors that are not under the control. Furthermore, agricultural production studies may be affected by measurement errors and the problem of omitting variables, further emphasis on the relevance of stochastic approaches is found in $(6,16)$.

Several studies have showed that technical efficiency estimates are sensitive to the functional form specifications and distributional form for the inefficiency term $(5,7$, 18). Additionally, a misspecified parametric model of the stochastic frontier and the error distribution can lead to biased efficiency results $(12,14,19)$. DEA techniques solve most of the relevant limitations of SFA: no specific functional forms are required. Nonetheless, nonparametric approaches do not allow for stochastic variables and measurement errors, which doesn't separate inefficiency effects from random noise or random shocks, i.e., all production shortfalls are attributed to the inefficiency term.

As a result, technical efficiency scores from the nonparametric approach (DEA) are, in generally, lower than those obtained from the parametric alternative (SFA) (17, 25). However, both methods have been found to have similar rankings of technical performance of Decision Making Units (DMUs). The objective of this study is to measure technical efficiency ratings of the agricultural production sector for individual African countries to understand whether economic agents optimally use their resources to reach their production objectives, additionally, study the effect of exogenous factors like total value of agricultural exports and agricultural land equipped for irrigation on the agricultural sectors' technical inefficiencies of the studied African countries. To address our objective, we adopt a True Random Effects (TRE) model for panel estimation following Greene (9) using simulated maximum likelihood for simultaneous estimation of the parameters of the stochastic frontier model and the technical inefficiency model. The contribution of this work is that, compared with the previous literature, TRE model allows to disentangle time-varying inefficiency from the unit time invariant unobserved heterogeneity.

The remainder of this paper is organized as follows. Section 2 presents a review of the literature assessing technical efficiency of the agricultural sector. Section 3 presents the methodological approach. Section 4 reports and analyzes the empirical results. Section 5 offers the concluding remarks. 


\section{Agricultural sector in Africa}

The agricultural sector in Africa is considered the main driver of economic development and is found to be parallel to the agricultural sector in South America and less but comparable to Asia. The main factor affecting agricultural growth in Africa is found to be labor and increasing agricultural land (1). Africa is dominated by family farming which depends on family labor, where a 33 million farms with less than two hectares representing $80 \%$ of all farms. During the last 10 years, large investments in Africa has been directed to agriculture covering 20 million hectares. In terms of policies, the Comprehensive Africa and Development Programme (CAADP) has been the main driver for identifying priorities and a channel of communication with the technical and financial partners. In 2010, out of 44 African countries only 9 have achieved or exceeded the target of spending $10 \%$ of governmental expenditure on agriculture (1).

Agricultural production in Africa has been tripled since the last 30 years and growth in agriculture was affected mainly by increased land and labor with little improvements in yields and no change in production techniques, however, these characteristics do vary from one region to another (1). In 2010 [1980], the total food crop production in Africa reached 562 [211] million tons. The share of north and east Africa to the total African food production reached 39\% [42\%] while western, central and southern Africa share to the total African food production represents 61\% [58\%]. North Africa is similar to the case of Asia with respect to the scarce availability of land so agriculture growth is increased by using intensive agriculture. Western Africa has gone through a sustained growth and exceeded many Asian countries in terms of labor productivity, increased yields and increasing agricultural land. Regarding the situation of East and Central Africa the performance was unsatisfactory due to political instability and poor climatic conditions (1). Technological innovations that have been adopted in food sectors had a significant growth; like cassava in western Africa through using new varieties and effective distribution techniques for the local markets; wheat harvesting methods in Egypt. In spite of the availability of water resources, a small proportion of land that uses irrigation. The variability of precipitation in time and space in all areas range from less than $100 \mathrm{~mm}$ to more than $3000 \mathrm{~mm}$ of rain annually which is considered very large leading to high variability in yields. Only five countries that uses irrigation which represents $6 \%$ of the total cultivated land in Africa including (Egypt, Morocco, Sudan, South Africa and Madagascar), moreover, with no water management, yields will be affected dramatically by climatic changes (1).

Food markets are considered very dynamic by taking advantage of local, national and regional markets. Several factors can help boosting food production; the 


\section{ri rq State of the Agricultural Sector Technical Efficiency:}

\section{The Case Study of African Countries}

development of a strong market infrastructure and transportation network that facilitate the supply of food; Due to the weak organization of agricultural sector in Africa, agricultural producers started to organize themselves and improve the quality of their products in the market (1).

Livestock production has benefited from growing markets owing to the increased urban demand. With rapid urbanization and increased incomes, higher consumption of animal protein is associated. Though, local production has not always met this growing demand due to frequent drought in the Sahel and in East Africa has impacted production negatively making its way for imports from outside of Africa (1). The majority of food products consumed by the African urban population is provided by local production. Exports of traditional crops (coffee, cocoa, cotton, palm oil, etc...) have received less interest due to facing challenges like increased prices volatilities in export markets which have decreased the interest in investment in these sectors, additionally, increased taxes on these exports have reduced its competitiveness in the international market. Finally, the focus was shifted to mining and oil industries since it generates more foreign income more quickly (1).

\section{Methodology}

There are two main approaches extensively used in the literature to measure technical efficiency: parametric SFA and non-parametric DEA. To take care of the identification problem caused from non-parametric models, SFA is used as alternative. The SFA approach, was commenced simultaneously by $(2,15)$, makes a distinction between exogenous shocks outside the control and inefficiency of the firm. In contrast to DEA, SFA takes into account random noise and allows for conventional tests of hypotheses. Additionally, SFA require the specification of a functional form for the production function and a distributional assumption for the inefficiency term. Agricultural production is stochastically determined since it is affected by climatic changes, and the agricultural production literature is likely affected by measurement and variable omission errors $(6,7,16)$, choosing a robust model is vital to consider these problems. We adopt a TRE stochastic production function following Greene (9) with the model presentation:

$$
\begin{aligned}
& y_{i t}=\alpha_{i}+X_{i t}^{\prime} \beta+\varepsilon_{i t} \\
& \varepsilon_{i t}=v_{i t}-u_{i t}
\end{aligned}
$$

where $y_{i t}$ denotes the level of output of country i at time t, $\boldsymbol{X}_{i t}$ is a vector of input quantities of the $i$-th country at time t. $\beta$ is a vector of parameters to be estimated. Component $\alpha_{i}$ in equation (1) is the random country specific effect, this specification 
allows to disentangle time-varying inefficiency from unit specific time invariant unobserved heterogeneity. The error term $\varepsilon_{i t}$ in equation (2) can be decomposed into two components; The first component, $v_{i t}$ is a normally distributed disturbance capturing the random variation in output due to statistical noise that occurs due to the unintended omission of relevant variables from vector $\boldsymbol{X}_{i t}$; measurement errors and approximation errors associated with the choice of the functional form; unexpected stochastic the control of the industry. Component $v_{i t}$ is usually assumed to be symmetric, independent and identically distributed as $\mathrm{N}\left(0, \sigma_{v}^{2}\right)$. The second component $u_{i t}$ is a one-sided, non-negative random variable, representing the stochastic shortfall of the $i$-th country output from its production frontier, assumed to be independently distributed following a truncated normal with mean $\left(Z_{i t} \delta\right)$ and variance $\sigma^{2}, Z_{i t}$ is a vector of exogenous variables associated with the inefficiency of production of countries over time distribution (4). Compared with previous literature on panel stochastic frontiers, this specification can differentiate unit specific time invariant unobserved heterogeneity and time varying inefficiency. To this end, TRE model is specified and is estimated using a Simulated Maximum Likelihood (SML). We have specified the following technical inefficiency effects model:

$u_{i t}=\delta Z_{i t}+\xi_{i t}$

where $u_{i t}$ is the technical inefficiency for country $i$ at time $t$, obtained from the stochastic frontier model and $\xi_{i t}$ is the error term. Selection of $Z_{i t}$ variables is based on previous literature and data availability. The method of estimated is the simulated maximum likelihood for simultaneous estimation of the parameters of the stochastic frontier model and the technical inefficiency model following (9).

\section{Results}

The present empirical application aims at studying the factors influencing the technical inefficiency of African countries' agricultural sectors using SFA approach applied on a panel dataset obtained from (http://www.ers .usda.gov/). Our sample consist of 26 African country for the time period 1961-2011 yielding a total of 1326 observations. The analysis was carried out using the econometric software Stata 12 . The SFA model estimates are obtained with a Cobb-Douglass functional form:

$y_{i t}=\alpha_{i}+\beta_{1} x_{1 i t}+\beta_{2} x_{2 i t}+\beta_{3} x_{3 i t}+\beta_{4} x_{4 i t}+\beta_{5} x_{5 i t}+\left(v_{i t}-u_{i t}\right)$

where the subscript $i=1,2, \ldots, N$ denotes the country number and $t=1,2, \ldots, N$ denotes the time period. The dependent variable $\left(y_{i t}\right)$ is the gross agricultural output as the sum of the value of production of 189 crop and livestock commodities valued at 


\section{The Case Study of African Countries}

constant, global-average prices, of the $i$-th country for time $t$. The inputs includes: $\left(x_{1 i t}\right)$ total agricultural land in hectares (the sum of rainfed cropland, irrigated cropland and permanent pasture that is used for forage crops either by cultivation or growing naturally); $\left(x_{2 i t}\right)$ the number of economically active adults in agriculture which is all persons involved or seeking employment in the work of family farming; $\left(x_{3 i t}\right)$ is the total livestock capital on farms in terms of cattle equivalent for different types of animals like (dairy and non-dairy cattle, goats and sheep, poultry, camel and horses); $\left(x_{4 i t}\right)$ represent the total stock of farm machinery in 40-CV (CV = metric horsepower) tractor equivalent summing 2-wheel tractors, 4-wheel tractors and combine harvesters; $\left(x_{5 i t}\right)$ is the metric tonnes of $\mathrm{N}, \mathrm{P} 2 \mathrm{O} 5, \mathrm{~K} 2 \mathrm{O}$ fertilizer consumption measured in $\mathrm{N}$ fertilizer equivalent. The African countries considered in the analysis are categorized into four groups; group one and two represents northern and eastern Africa respectively and group three and four represent central and western Africa respectively as presented in table 1. Summary statistics for the variables by groups used in the analysis are presented in table 2 . The summary statistics show the relative similarity among the four groups in terms of output, land, livestock and labour, and heterogeneity in Machinery and fertilizer. In inefficacy model is estimated to study the effects of exogenous variables (two variables are considered in the analysis) on technical inefficiencies with the following specification

$$
u_{i t}=\alpha+\beta_{1} x_{i t t}+\beta_{2} x_{7 i t}+\xi_{i t}
$$

Table 1. Countries and country groups

\begin{tabular}{|c|c|c|c|c|c|}
\hline $\begin{array}{c}\text { Country } \\
\text { code }\end{array}$ & $\begin{array}{c}\text { Group } \\
\text { code }\end{array}$ & Country & $\begin{array}{c}\text { Country } \\
\text { code }\end{array}$ & $\begin{array}{c}\text { Group } \\
\text { code }\end{array}$ & Country \\
\hline $\mathbf{1}$ & 1 & Egypt & 15 & 3 & Cameron \\
\hline $\mathbf{2}$ & 1 & Algeria & 16 & 3 & Central Africa \\
\hline $\mathbf{3}$ & 1 & Morocco & 17 & 3 & Chad \\
\hline $\mathbf{4}$ & 1 & Sudan & 18 & 3 & Eq. Guinea \\
\hline $\mathbf{5}$ & 1 & Tunisia & 19 & 4 & Ghana \\
\hline $\mathbf{6}$ & 2 & Burundi & 20 & 4 & Mali \\
\hline $\mathbf{7}$ & 2 & Kenya & 21 & 4 & Niger \\
\hline $\mathbf{8}$ & 2 & Madagascar & 22 & 4 & Nigeria \\
\hline $\mathbf{9}$ & 2 & Malawi & 23 & 4 & Burkina Faso \\
\hline $\mathbf{1 0}$ & 2 & Mozambique & 24 & 4 & Cote devoir \\
\hline $\mathbf{1 1}$ & 2 & Rwanda & 25 & 4 & Mauritania \\
\hline $\mathbf{1 2}$ & 2 & Uganda & 26 & 4 & Senegal \\
\hline $\mathbf{1 3}$ & 2 & Tanzania & 27 & & \\
\hline $\mathbf{1 4}$ & 3 & Angola & 28 & & \\
\hline
\end{tabular}




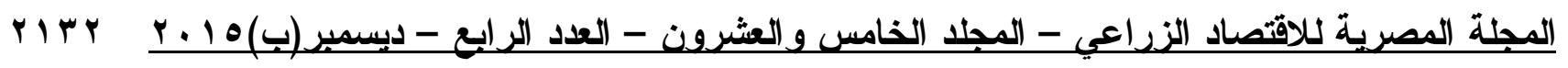

Table 2. Summary statistics for variables in the analysis

\begin{tabular}{|c|c|c|c|c|}
\hline Variable & Mean & Std. dev. & Min & Max \\
\hline \multicolumn{5}{|c|}{ Group 1 - North Africa } \\
\hline Output & 15.197 & 0.703 & 13.704 & 16.963 \\
\hline Land & 8.879 & 0.414 & 8.173 & 9.855 \\
\hline Labour & 7.891 & 0.787 & 6.387 & 8.932 \\
\hline Livestock & 8.997 & 0.896 & 7.485 & 11.101 \\
\hline Machinery & 10.266 & 0.880 & 7.467 & 11.623 \\
\hline Fertilizer & 11.944 & 1.100 & 9.366 & 14.326 \\
\hline Exports & 12.614 & 1.352 & 9.285 & 14.909 \\
\hline Irrigation & 6.794 & 0.974 & 4.605 & 8.207 \\
\hline \multicolumn{5}{|c|}{ Group 2 - East Africa } \\
\hline Output & 14.410 & 0.690 & 12.985 & 15.919 \\
\hline Land & 8.010 & 0.702 & 6.255 & 9.582 \\
\hline Labour & 8.368 & 0.612 & 7.137 & 9.763 \\
\hline Livestock & 8.157 & 1.263 & 6.255 & 10.335 \\
\hline Machinery & 7.123 & 2.145 & 0.693 & 9.977 \\
\hline Fertilizer & 8.894 & 1.937 & 3.912 & 12.354 \\
\hline Exports & 12.081 & 1.210 & 9.433 & 14.379 \\
\hline Irrigation & 3.531 & 1.633 & 0.693 & 6.991 \\
\hline \multicolumn{5}{|c|}{ Group 3 - Central Africa } \\
\hline Output & 13.179 & 1.442 & 10.114 & 15.505 \\
\hline Land & 7.116 & 1.302 & 4.417 & 8.704 \\
\hline Labour & 6.991 & 1.270 & 4.177 & 8.733 \\
\hline Livestock & 7.131 & 2.362 & 2.117 & 9.402 \\
\hline Machinery & 5.572 & 1.948 & 2.302 & 9.671 \\
\hline Fertilizer & 7.911 & 1.997 & 2.302 & 10.889 \\
\hline Exports & 10.590 & 1.840 & 7.198 & 14.123 \\
\hline Irrigation & 2.912 & 1.413 & 0.693 & 4.553 \\
\hline \multicolumn{5}{|c|}{ Group 4 - West Africa } \\
\hline Output & 14.317 & 1.168 & 12.353 & 17.403 \\
\hline Land & 8.366 & 0.967 & 6.662 & 10.767 \\
\hline Labour & 7.784 & 0.893 & 5.886 & 9.459 \\
\hline Livestock & 8.515 & 0.892 & 6.201 & 10.527 \\
\hline Machinery & 6.701 & 1.704 & 1.871 & 10.120 \\
\hline Fertilizer & 9.253 & 2.040 & 3.673 & 13.383 \\
\hline Exports & 12.477 & 1.582 & 7.577 & 15.505 \\
\hline Irrigation & 3.725 & 1.160 & 0.693 & 5.680 \\
\hline
\end{tabular}




\section{The Case Study of African Countries}

where the subscript $i=1,2, \ldots, N$ denotes the country number and $t=1,2, \ldots, N$ denotes the time period. The dependent variable $\left(u_{i t}\right)$ is the technical inefficiency obtained from stochastic frontier model; $\left(x_{6 i t}\right)$ is total agricultural exports value obtained from ()$;\left(x_{7 i t}\right)$ is the total agriculture land equipped for irrigation. It is noteworthy that since the paper investigates the agricultural sectors for African countries, it is hard to find aggregate measures for all countries for the indicated time period.

Results of the estimated stochastic frontier models presented in (table 3) for the four groups of African countries and for all the African countries pooled. Results of the production elasticity estimates indicate that, for all African countries, increases in the agricultural land area has the largest effect on total agricultural output. In terms of productivity, land, livestock and labour have the biggest impacts, respectively. This results are compatible with (1) that identified these factors of production are the most productive in the African agriculture sector. While in different countries groups, agricultural production factors effects vary. Agricultural land area is found to have the largest contribution in groups two, three and four compared to group one. This is an expected results, since countries in group one is dependent on old agricultural land that are faced by risk of soil degradation and new lands are sandy soils that require years for land reclamation for agricultural production. Labour has the highest effect in group one followed by group two and three, respectively.

The high contribution of labour to productivity in group one compared with other groups can be attributed to that the high level of training of labour in this group which is also justified with the highest contribution of machinery to agricultural output in as well due to the proximity of the European Union in importing new technologies. Livestock has the biggest effect in group four compared with other country groups. Conversely, fertilizer use is found to have the smallest effect in increasing agricultural production for individual groups with a higher contribution in group one compared with other groups. Regarding the scale elasticity, the four groups show an increasing returns to scale the indicating the potential increase of the agricultural sector size for these countries and through taking advantage of economies of scale.

As noted in the empirical framework presented above, only two explanatory variables are used as factors influencing the technical inefficiency due to the problem of data unavailability. Parameter estimates of the inefficiency model are shown in table 3. Results indicate that land equipped for irrigation is found to be statistically relevant in groups 1, 2 and 3 with negative effect on technical inefficiency of the agricultural sector. 
Agricultural exports is found to have a statistically significant positive effect on the technical inefficiency in groups 1 and 3 with a greater impact in group 3, given that the percentage of exports to imports in Central Africa reached 49\% compared with 27\% in north Africa in 2010 (1). Technical efficiency scores are calculated following Battese and Coelli (3) and presented in figures 1 through 4. Table 4 shows the summary statistics for technical efficiency scores of African countries groups. Figure 1 shows that technical efficiency scores exhibits an upward trend indicating an increase in the efficiency over time, as indicated above the main factors affecting the growth of agriculture is increasing labour and agricultural land productivity. On the other hand, other groups doesn't show a positive trend of technical efficiency.

Table 3. Parameter estimates of the stochastic frontier models (True Random Effects)

\begin{tabular}{|c|c|c|c|c|c|}
\hline & $\begin{array}{c}\text { All } \\
\text { countries }\end{array}$ & $\begin{array}{c}\text { Group } 1 \\
\text { (North } \\
\text { Africa) }\end{array}$ & $\begin{array}{c}\text { Group } 2 \\
\text { (Eastern } \\
\text { Africa) }\end{array}$ & $\begin{array}{c}\text { Group } 3 \\
\text { (Central } \\
\text { Africa) }\end{array}$ & $\begin{array}{c}\text { Group } 4 \\
\text { (Western } \\
\text { Africa) }\end{array}$ \\
\hline Land & $\begin{array}{c}0.600^{* * *} \\
(0.038)\end{array}$ & $\begin{array}{c}-0.107 \\
(0.094)\end{array}$ & $\begin{array}{c}0.524 * * * \\
(0.047)\end{array}$ & $\begin{array}{c}0 . .331 * * * \\
(0.043)\end{array}$ & $\begin{array}{c}0.592 * * * \\
(0.023)\end{array}$ \\
\hline Labour & $\begin{array}{c}0.167 * * * \\
(0.016)\end{array}$ & $\begin{array}{c}0.480 * * * \\
(0.070)\end{array}$ & $\begin{array}{c}0.323 * * * \\
(0.034)\end{array}$ & $\begin{array}{c}0.378 * * * \\
(0.049)\end{array}$ & $\begin{array}{c}0.082 * * * \\
(0.026)\end{array}$ \\
\hline Livestock & $\begin{array}{c}0.471^{* * *} \\
(0.018)\end{array}$ & $\begin{array}{c}0.324 * * * \\
(0.052)\end{array}$ & $\begin{array}{c}0.357 * * * \\
(0.033)\end{array}$ & $\begin{array}{c}0.390 * * * \\
(0.032)\end{array}$ & $\begin{array}{c}0.604 * * * \\
(0.029)\end{array}$ \\
\hline Machinery & $\begin{array}{l}0.015^{* *} \\
(0.006)\end{array}$ & $\begin{array}{c}0.443 * * * \\
(0.029)\end{array}$ & $\begin{array}{l}-0.009 \\
(0.007)\end{array}$ & $\begin{array}{l}-0.035 \\
(0.025)\end{array}$ & $\begin{array}{c}-0.001 \\
(0.010)\end{array}$ \\
\hline Fertilizer & $\begin{array}{c}0.036^{* * *} \\
(0.005)\end{array}$ & $\begin{array}{c}0.075^{* * *} \\
(0.024)\end{array}$ & $\begin{array}{c}0.018^{* *} \\
(0.007) \\
\end{array}$ & $\begin{array}{c}0.070^{* * *} \\
(0.011)\end{array}$ & $\begin{array}{c}0.030^{* * * *} \\
(0.006)\end{array}$ \\
\hline $\begin{array}{c}\text { Returns to } \\
\text { scale } \\
\end{array}$ & 1.290 & 1.215 & 1.213 & 1.134 & 1.334 \\
\hline \multicolumn{6}{|c|}{ Parameter estimates of the inefficiency model } \\
\hline Exports & $\begin{array}{c}0.034 * * * \\
(0.004)\end{array}$ & $\begin{array}{c}0.075 * * * \\
(0.023)\end{array}$ & $\begin{array}{l}-0.012 \\
(0.011)\end{array}$ & $\begin{array}{c}0.160 * * * \\
(0.015)\end{array}$ & $\begin{array}{c}0.008 \\
(0.007)\end{array}$ \\
\hline Irrigation & $\begin{array}{c}-0.043^{* * *} \\
(0.009) \\
\end{array}$ & $\begin{array}{c}-0.469 * * * \\
(0.065)\end{array}$ & $\begin{array}{c}-0.031^{* * *} \\
(0.011) \\
\end{array}$ & $\begin{array}{c}-0.124 * * * \\
(0.025) \\
\end{array}$ & $\begin{array}{c}-0.017 \\
(0.002) \\
\end{array}$ \\
\hline $\begin{array}{c}\text { Log } \\
\text { simulated- } \\
\text { likelihood }\end{array}$ & 464.247 & 100.464 & 332.850 & 95.717 & 298.947 \\
\hline
\end{tabular}

$* * *(* *)$ indicate significance level $1 \%(5 \%)$

Standard errors in parenthesis 
State of the Agricultural Sector Technical Efficiency:

The Case Study of African Countries

Figure 1. Technical efficiencies of group one African countries

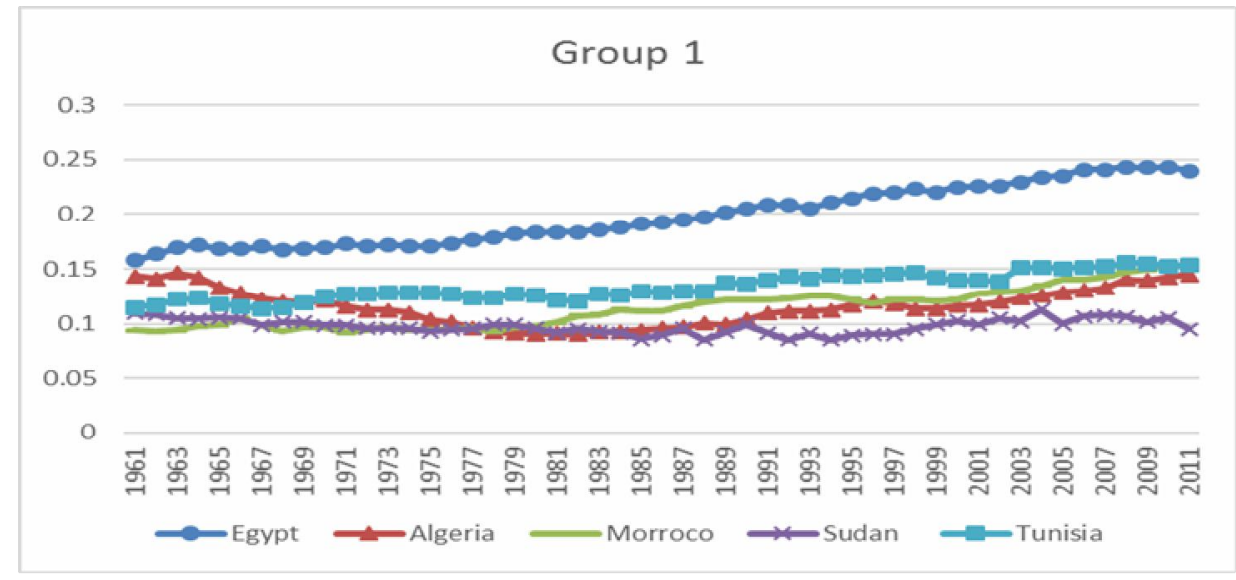

Figure 2. Technical efficiencies of group two African countries

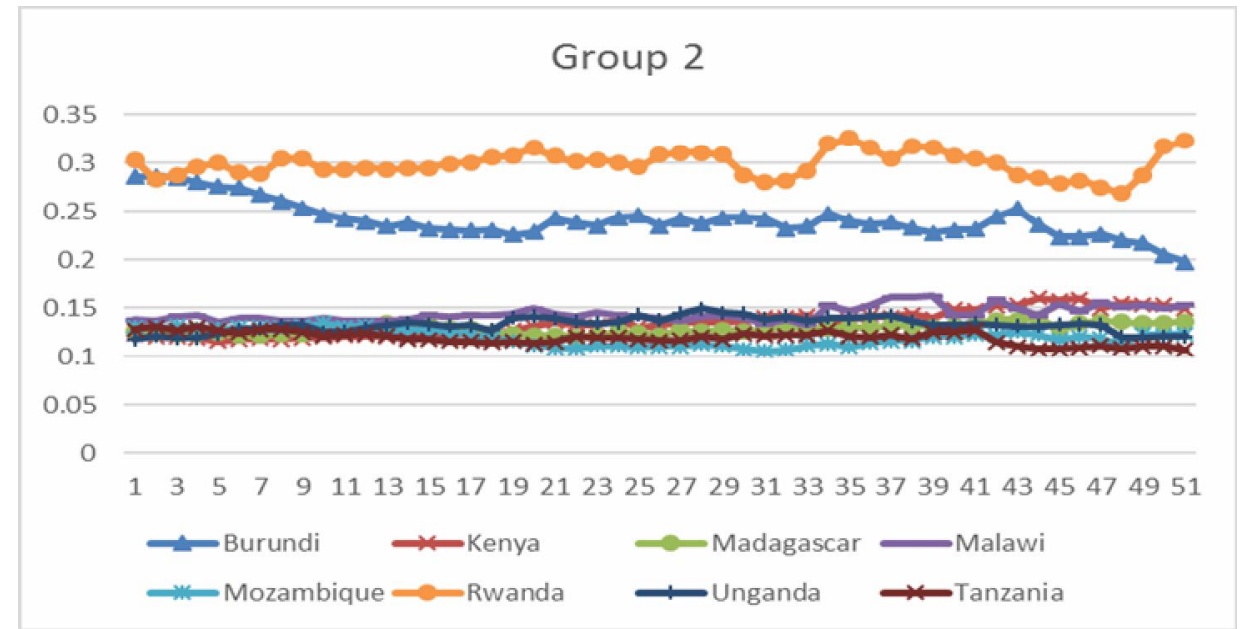

Figure 3. Technical efficiencies of group three African countries

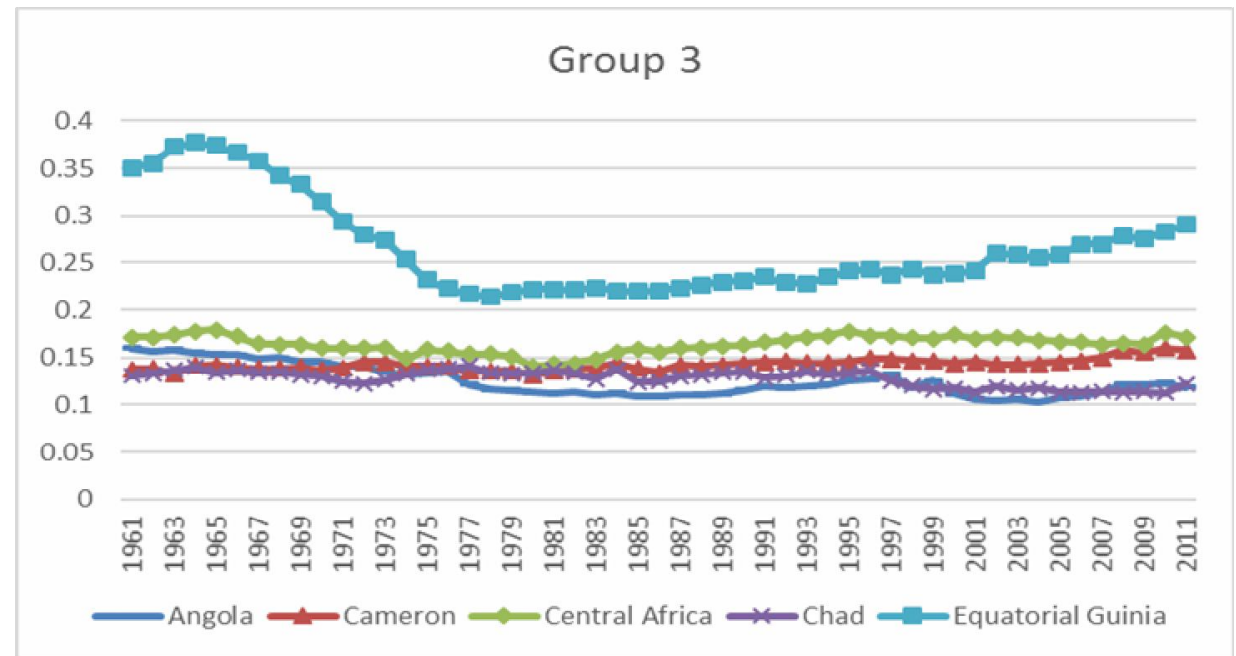




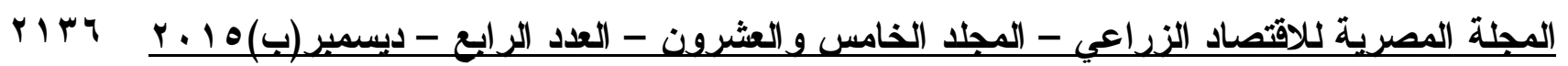

Figure 4. Technical efficiencies of group four African countries

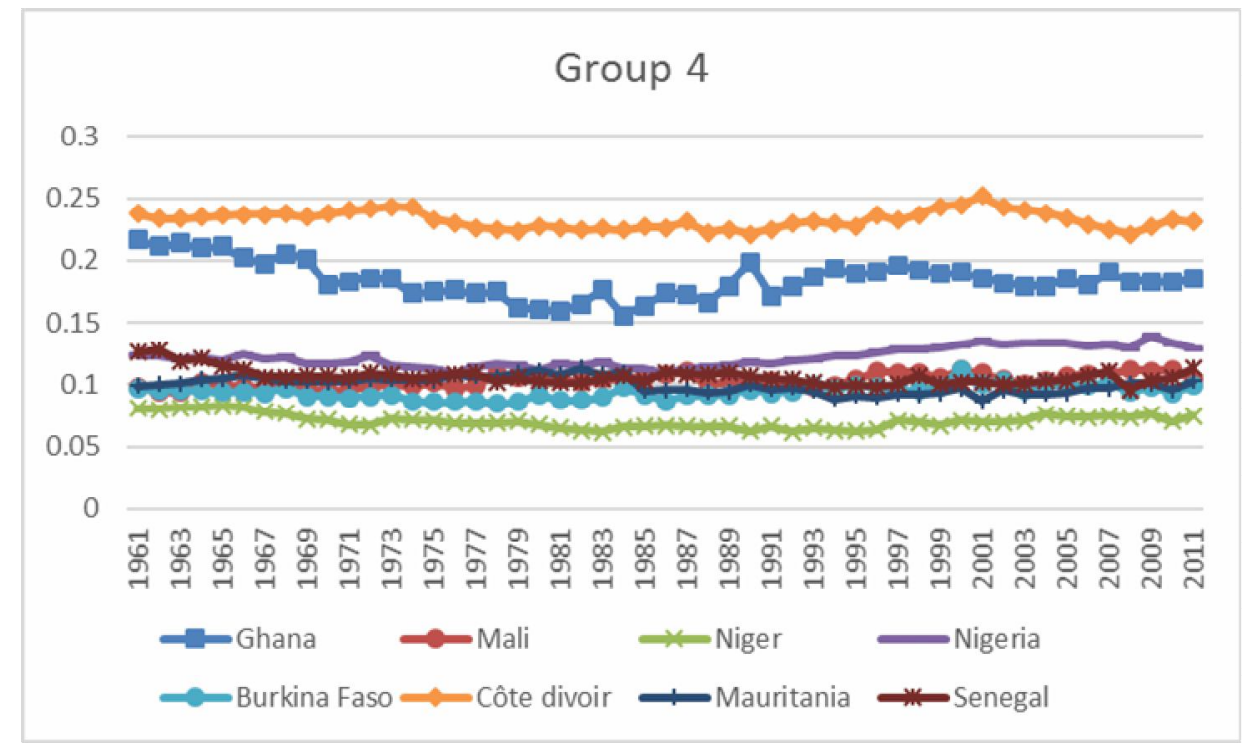

Table 4. Summary statistics for technical efficiency scores

\begin{tabular}{|c|c|c|c|c|c|c|}
\hline & Mean & $\begin{array}{c}\text { Std. } \\
\text { Dev. }\end{array}$ & Min & max & \multicolumn{2}{c|}{$\begin{array}{c}\text { Confidence } \\
\text { interval (95\%) }\end{array}$} \\
\hline \multicolumn{1}{|c|}{ All countries } & 0.146 & 0.058 & 0.061 & 0.377 & 0.143 & 0.149 \\
\hline Group 1: (North Africa) & 0.131 & 0.039 & 0.085 & 0.243 & 0.127 & 0.136 \\
\hline Group 2: (Eastern Africa) & 0.164 & 0.063 & 0.105 & 0.325 & 0.159 & 0.171 \\
\hline Group 3: (Central Africa) & 0.165 & 0.057 & 0.103 & 0.377 & 0.158 & 0.172 \\
\hline Group 4: (Western Africa) & 0.126 & 0.051 & 0.061 & 0.252 & 0.121 & 0.131 \\
\hline
\end{tabular}

Improving technical efficiency allows reducing production costs and increases competitiveness, which can help farmers face changing market conditions and poor economic circumstances. As market conditions change and consumers become more demanding, and retailers in the marketing chain increase their marketing power, farm margins can be squeezed. In this line, improving technical efficiency can help farmers endure times of economic hardship. A strategy based on cost reduction relevant in the agriculture sector through improving local and regional markets infrastructure and transportation networks among regions in Africa. However, focusing only on improving technical efficiency is not sufficient to be more competitive and economically efficient. Farmers also need to improve their allocative efficiency, an important component of economic efficiency. Future extension of our work will concentrate on the analysis of 


\section{The Case Study of African Countries}

allocative efficiency for agricultural subsectors, the second component of economic efficiency and the study total factor productivity and its components for each group.

\section{Conclusions}

The agricultural sector constitutes a large portion of the economies in Africa, which can help in solving major issues like malnutrition and hunger. Reducing postharvest losses and sustainable resource and environmental management. Two main factors affect agricultural growth including labour and agricultural land, besides Africa is dominated by family farming with 33 million. Food markets are considered very dynamic through taking advantage of local, national and regional markets. Several factors can help boosting food production; the development of a strong market infrastructure and transportation network that facilitate the supply of food (1).

The objective of this study is to study the factors affecting the technical inefficiency of the agricultural production sector for individual African countries. To address our objective a True Random Effects (TRE) model is applied following Greene (2005). The method of estimated is the simulated maximum likelihood for simultaneous estimation of the parameters of the stochastic frontier model and the technical inefficiency model. The results obtained from the stochastic frontier analysis using 26 country agricultural sector data for 51 years for the period 1961-2011 provide information on the output elasticity of different inputs for different groups; we find that agricultural land, labor and livestock are the most productive inputs. All groups exhibit increasing rate of return to scale meaning agricultural sectors in the respective groups could become more profitable with larger operations. Our empirical findings in the inefficiency equation indicate that agricultural exports has a significant positive effect on technical inefficiency in group one and three, while land equipped for irrigation found to have a significant negative effect on technical inefficiency in groups one, two and three. Results of the efficiency scores show, on average, that group one exhibit and upward trend compared with other groups.

Based on our results, this information could help policymakers understand how to apply any new policies. For example, making new investment plans for introducing advanced irrigation systems and adopting new production practices that may help increasing farms' technical efficiencies which in turn will help increasing agricultural output and reduce the variability of yields. Additionally, improving local markets infrastructure and logistics which will help smoothing the supply of food and facing 
international markets volatilities. Considering that Africa is ruled by family farming which represent $80 \%$ of all farms (1) improving technical efficiency allows reducing production costs and improving competitiveness that can help farmers face fluctuating market conditions and economic hardships. As markets change, consumers become more demanding and middlemen in the supply chain and retailers increase their marketing power causing farm margins to be squeezed. In this regard, improving technical efficiency can help farmers endure times of hard economic situations. Establishing and committing to a common agricultural policy like the Comprehensive Africa Agriculture Development Programme (CAADP) to be a promoter for African initiatives which will help regulate the information flow with technical and financial partners.

\section{References}

(1) Agriculture in Africa, 2014. New Partnership for African Development (NEPAD), 2014. Available at: http://www. nepad.org/foodsecurity/ knowledge/doc/3232/agriculture-africa. (Last accessed June 2014)

(2) Aigner, D., Lovell, C.A.K., Schmidt, P., 1977. Formulation and estimation of stochastic frontier production functions models. Journal of Econometrics 6: 21-37.

(3) Battese, G., and Coelli, T., 1988. Prediction of firm-level technical efficiencies with a generalized frontier production function and panel data. Journal of Econometrics 38: 387-399.

(4) Battese, G., and Coelli, T., 1995. A model for technical inefficiency effects in a stochastic frontier production function for panel data. Empirical Economics 20: 325332.

(5) Chakraborty, K., Biswas, B., Lewis, W.C., 2001. Measurement of technical efficiency in public education: A stochastic and nonstochastic production function approach. Southern Economic Journal 67: 889-905.

(6) Chakraborty, K., Misra, S., Johnson, P., 2002. Cotton farmers' technical efficiency: stochastic and non-stochastic production function approaches. Agricultural and Resource Economics Review 31:211-220.

(7) Coelli, T.J., 1995. Recent developments in frontier modeling and efficiency measurement. Australian Journal of Agricultural and Resource Economics 39: 219245. 
rirq State of the Agricultural Sector Technical Efficiency:

\section{The Case Study of African Countries}

(8) Coelli, T.J., Perelman, S., 1999. A comparison of parametric and non-parametric distance functions: With application to European railways. European Journal Operational Research 117: 326-339.

(9) Greene, W., 2005. Reconsidering heterogeneity in panel data estimators of the stochastic frontier model. Journal of Econometrics 126: 269-303.

(10) Hayami, Y., Ruttan, V.W., 1970. Agricultural productivity differences among countries. American Economic Review 40: 895-911.

(11) Kawagoe, T., Hayami, Y., Ruttan, V., 1985. The intercountry agricultural production function and productivity differences across countries. Journal of Development Economics x 19: 113-132.

(12) Kumbhakar, S.C., Byeong, U.P., Simar, L., Tsionas E.G., 2007. Nonparametric stochastic frontiers: A local maximum likelihood approach. Journal of Econometrics 137: 1-27.

(13) Lau, L.J., Yotopoulos, P.A., 1989. The meta-production function approach to technological change in world agriculture. Journal of Development Economics 31: 241269.

(14) Martins-Filho, C., Yao, F., 2007. Nonparametric frontier estimation via local linear regression. Journals of Econometrics 141: 283-319.

(15) Meeusen, W., Van Den Broek, J., 1977. Efficiency estimation from Cobb-Douglas production functions with composed error. International Economic Review 18: 435444.

(16) Oude Lansink, A., Pietola, K., Bäckman, S., 2002. Efficiency and productivity of conventional and organic farms in Finland 1994-1997. European Review of Agricultural Economics 29: 51-65.

(17) Puig-Junoy, J., Argiles, J.M., 2000. Measuring and explaining farm inefficiency in a panel data set of mixed Farms. Pompeu Fabra University, Working Paper, Barcelona, Spain.

(18) Ruggiero, J., Vitaliano, D., 1999. Assessing the efficiency of public schools using data envelopment analysis and frontier regression. Contemporary Economic Policy 17: 321331 .

(19) Serra, T., Goodwin, B.K., 2009. The efficiency of Spanish arable crop organic farms, a local maximum likelihood approach. Journal of Productivity Analysis 3: 113-124. 


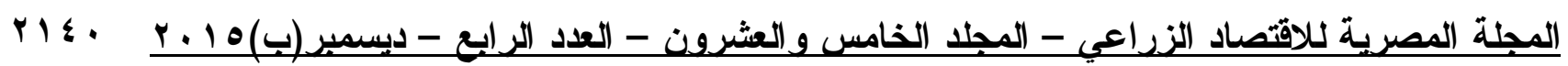

(20) Sipiläinen, T., Oude Lansink A., 2005. Learning in organic farming-an application on Finnish dairy farms. Manuscript presented at the XIth Congress of the EAAE. Copenhagen, Denmark, August 24-17.

(21) Sipiläinen, T., Kuosmanen, T., Kumbhakar, S.C., 2008. Measuring productivity differentials- An application to milk production in Nordic countries. 12th Congress of the European Association of Agricultural Economics - EAAE 2008.

(22) Trueblood, M.A., Ruttan, V.W. (1995) A comparison of multifactor productivity calculation of the US agricultural sector. Journal of Productivity Analysis 6: 321-32.

(23) Tzouvelekas, V., Pantzios, C.J., Fotopoulos, C., 2001. Technical efficiency of alternative farming systems: The case of Greek organic and conventional olivegrowing farms. Food Policy 26: 549-569.

(24) Tzouvelekas, V., Pantzios, C.J., Fotopoulos, C., 2002. Empirical evidence of technical efficiency levels in Greek organic and conventional farms. Agricultural Economics Review 3: 49-60.

(25) Wadud, A., White, B., 2000. Farm household efficiency in Bangladesh: A comparison of stochastic frontier and DEA methods. Applied Economics 32: 16573.

\section{حالة الكفاءة الفنية للقطاعات الزراعية: دراسة حالة للبلدان الأفريقية

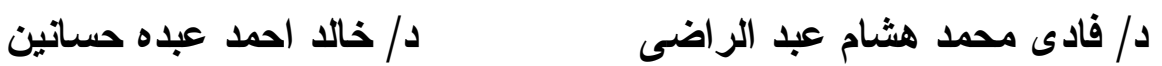 قسم الاقتصاد الزراعي - كلية الزراعة - جامعة القاهرة}

الملخص

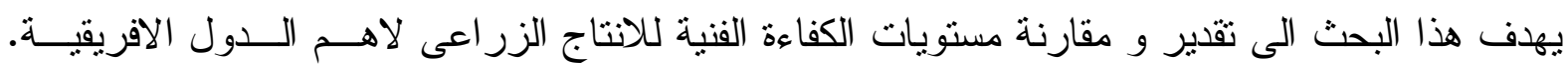

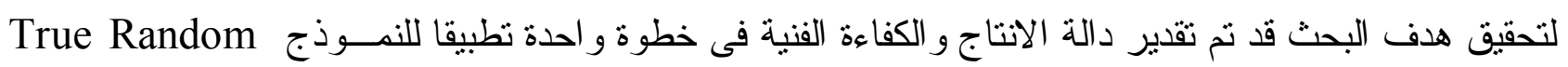

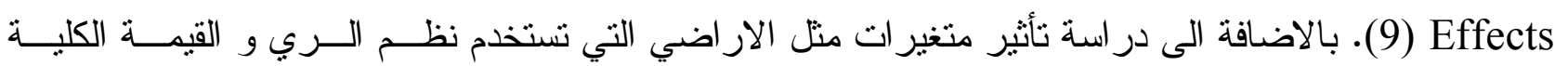
للصادر ات الزر اعية الافريقية على مستويات عدم الكفاءة الفنية. اعتدت الدراسة على البيانــات المتاحسـة عـنـ

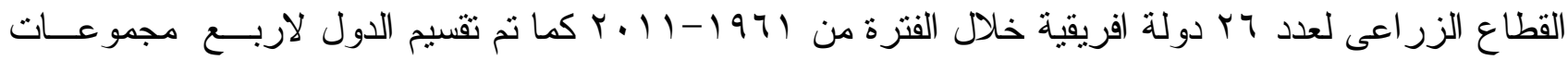
بناءا على النوزيع الجغر افى (الثنمال و الجنوب و الوسط و الغرب). 


\section{$Y \backslash 1 \quad$ State of the Agricultural Sector Technical Efficiency:}

\section{The Case Study of African Countries}

يشير التحليل الوصفي الى وجود فوارق بين تلك المجموعات خصوصا في راس المال الالى و اســتخدام الاسمدة. اظهرت نتائج النموذج القياسى ان عنصر العمل البشرى و راس المال الالى يشكلان اكثر المـــخلات

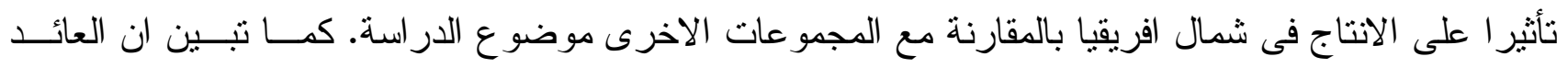

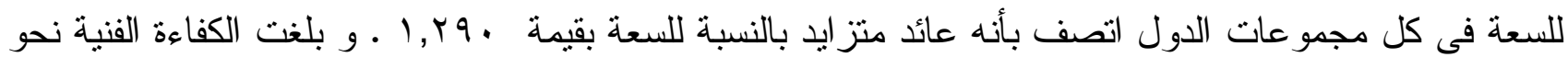

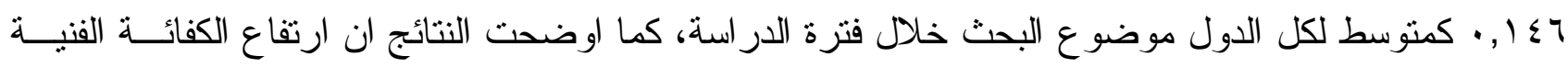

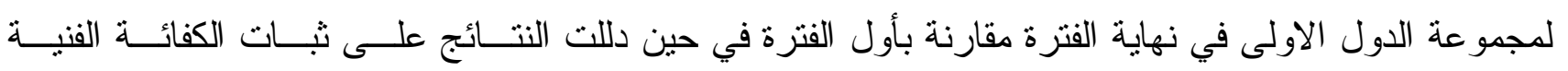

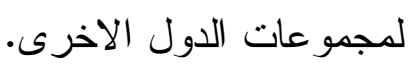

